\title{
Glaciimonas immobilis gen. nov., sp. nov., a member of the family Oxalobacteraceae isolated from alpine glacier cryoconite
}

Correspondence

Rosa Margesin

Rosa.Margesin@uibk.ac.at

\author{
De-Chao Zhang, Mersiha Redzic, Franz Schinner and Rosa Margesin
}

\begin{abstract}
Strains $\mathrm{Cr} 9-30^{\top}$ and $\mathrm{Cr} 9-12$ were isolated from alpine glacier cryoconite. Both strains were Gram-negative-staining, non-motile, rod-shaped and psychrophilic, showing good growth over the temperature range $1-20^{\circ} \mathrm{C}$. Phylogenetic analysis of $16 \mathrm{~S}$ rRNA gene sequences revealed that the two strains formed a distinct branch within the family Oxalobacteraceae and were most closely related to members of the genus Collimonas. The $16 \mathrm{~S}$ rRNA gene sequence similarity between strains $\mathrm{Cr} 9-30^{\top}$ and $\mathrm{Cr} 9-12$ was $99.0 \%$. The two strains showed highest $16 \mathrm{~S}$ rRNA gene sequence pairwise similarity with Collimonas pratensis LMG $23965^{\top}$ (96.6 and $96.1 \%$ for strains $\mathrm{Cr} 9-30^{\top}$ and Cr9-12, respectively), Collimonas arenae LMG $23964^{\top}$ (96.5 and $96.3 \%$, respectively) and Collimonas fungivorans LMG $21973^{\top}$ (96.4 and $96.2 \%$, respectively). The predominant cellular fatty acids were summed feature $3\left(\mathrm{C}_{16: 1} \omega 7 \mathrm{c}\right.$ and/or iso- $\left.\mathrm{C}_{15: 0} 2-\mathrm{OH}\right)$, $\mathrm{C}_{16: 0}$ and $\mathrm{C}_{18: 1} \omega 7 \mathrm{c}$. The DNA G $+\mathrm{C}$ content of strain $\mathrm{Cr} 9-30^{\top}$ was $51.0 \mathrm{~mol} \%$. On the basis of phenotypic characteristics and phylogenetic analysis, strains $\mathrm{Cr} 9-30^{\top}$ and $\mathrm{Cr} 9-12$ represent a novel species in a new genus of the family Oxalobacteraceae, for which the name Glaciimonas immobilis gen. nov., sp. nov. is proposed. The type strain of Glaciimonas immobilis is $\mathrm{Cr} 9-30^{\top}$ $\left(=\right.$ DSM $23240^{\top}=$ LMG $\left.25547^{\top}\right)$.
\end{abstract}

The bacterial family Oxalobacteraceae belongs to the class Betaproteobacteria and, at the time of writing, included 11 genera (Garrity et al., 2005; Kämpfer et al., 2007). The family Oxalobacteraceae represents a phylogenetically diverse family of typically aquatic and soil micro-organisms within the class Betaproteobacteria (Eder et al., 2011) and the majority of the organisms in this family form yellowish-pigmented colonies on nutrient-rich media such as nutrient agar (Kämpfer et al., 2007). Cold-adapted members within this family have been described recently, for example Herminiimonas glaciei was isolated from a Greenland glacier ice core (Loveland-Curtze et al., 2009) and Massilia brevitalea was detected in lysimeter soil (Zul et al., 2008). In the present paper, the characterization of two novel psychrophilic strains, designated $\mathrm{Cr} 9-30^{\mathrm{T}}$ and $\mathrm{Cr} 9-12$, is reported. The term psychrophile is used in this report as a general term to describe a microorganism that grows in a cold environment (Margesin et al., 2008). The use of growth rates to define the optimum growth temperature as described by Morita (1975) has been shown to be ambiguous and inappropriate (Feller \& Gerday, 2003; Cavicchioli, 2006; Margesin, 2009).

Strains $\mathrm{Cr} 9-30^{\mathrm{T}}$ and $\mathrm{Cr} 9-12$ were isolated from alpine glacier cryoconite collected under sterile conditions in

The GenBank/EMBL/DDBJ accession numbers for the 16S rRNA gene sequences of strains $\mathrm{Cr} 9-30^{\top}$ and $\mathrm{Cr} 9-12$ are GU441679 and HM756647, respectively. spring 2006 from the Tiefenbachferner glacier in the Oetztaler Alps, Tyrol, Austria, at an altitude of $2900 \mathrm{~m}$ above sea level. A sample (1 g dry mass) was shaken with $9 \mathrm{ml}$ sterile $1 \%$ sodium pyrophosphate for $20 \mathrm{~min}$ at 150 r.p.m. Appropriate dilutions, prepared with sterile saline solution $(0.9 \% \mathrm{NaCl})$, were plated on $\mathrm{R}_{2} \mathrm{~A}$ agar $(0.05 \%$ yeast extract, $0.05 \%$ peptone, $0.05 \%$ Casamino acids, $\quad 0.05 \%$ glucose, $0.05 \%$ starch, $0.03 \%$ sodium pyruvate, $0.03 \% \mathrm{~K}_{2} \mathrm{HPO}_{4}, 0.005 \% \mathrm{MgSO}_{4}, 1.5 \%$ agar, $\mathrm{pH} 7$; Reasoner \& Geldreich, 1985) and incubated at $10{ }^{\circ} \mathrm{C}$. Two pure white cultures were identified and designated Cr9-30 ${ }^{\mathrm{T}}$ and Cr9-12. Collimonas fungivorans LMG $21973^{\mathrm{T}}$ (type species of the genus), Collimonas arenae LMG $23964^{\mathrm{T}}$ and Collimonas pratensis LMG $23965^{\mathrm{T}}$ were routinely grown on $\mathrm{R}_{2} \mathrm{~A}$ agar at $20{ }^{\circ} \mathrm{C}$ and used as reference strains.

DNA was extracted and purified as described by Sambrook et al. (1989). The 16S rRNA gene was amplified by PCR with two universal primers (Zhang et al., 2010). PCR products were cloned in pGEM-T vectors (Promega) according to the manufacturer's instructions. Sequencing reactions were performed as described by Zhang et al. (2006). Phylogenetic analysis using the program MEGA version 3.0 (Kumar et al., 2004) revealed that strains $\mathrm{Cr} 9-30^{\mathrm{T}}$ and $\mathrm{Cr} 9-12$ formed a distinct phylogenetic lineage with a high bootstrap value $(100 \%)$ within the family Oxalobacteraceae in the neighbour-joining tree (Fig. 1). Strains Cr9-30 ${ }^{\mathrm{T}}$ and Cr9-12 had almost identical 16S rRNA 


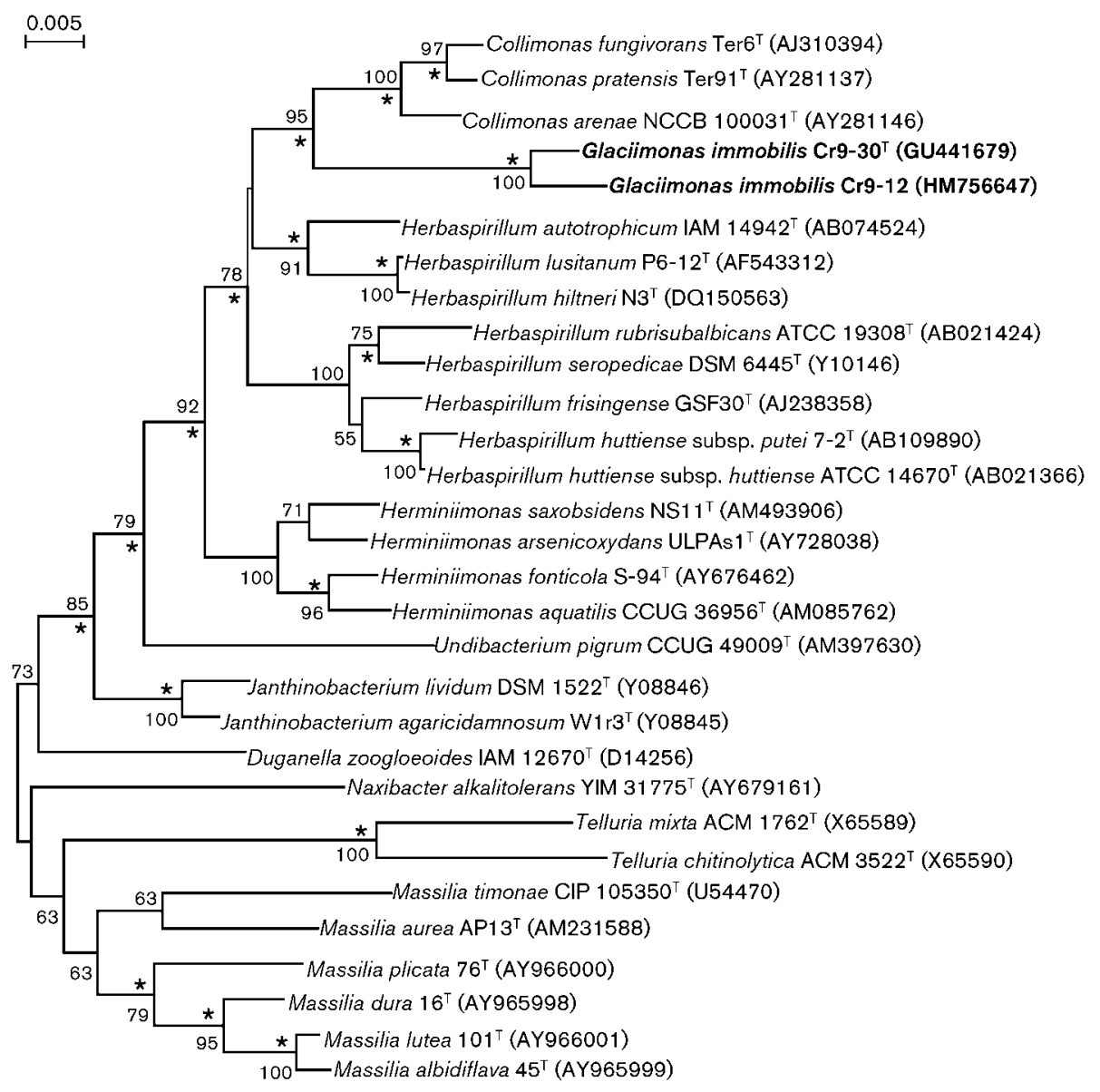

Fig. 1. Neighbour-joining tree, based on 16S rRNA gene sequence data, showing the phylogenetic position of strains Cr9-30', Cr9-12 and representatives of other related taxa. Bootstrap values (\%) are based on 1000 replicates and are shown for branches with $>50 \%$ support. Asterisks indicate nodes that were also found in the maximum-likelihood tree. GenBank accession numbers of $16 \mathrm{~S}$ rRNA gene sequences are given in parentheses. Bar, $0.5 \%$ sequence divergence.

gene sequences ( $99.0 \%$ similarity) and showed the highest $16 \mathrm{~S}$ rRNA gene sequence pairwise similarity with C. pratensis LMG $23965^{\mathrm{T}}$ (96.6 and $96.1 \%$ for $\mathrm{Cr} 9-30^{\mathrm{T}}$ and $\mathrm{Cr} 9-12$, respectively), C. arenae LMG $23964^{\mathrm{T}}$ (96.5 and $96.3 \%$, respectively) and C. fungivorans LMG $21973^{\mathrm{T}}$ (96.4 and $96.2 \%$, respectively). In addition, a similar tree topology was also found in the tree generated with the maximum-likelihood method in the PHYLIP 3.69 package (Felsenstein, 2009) after sequences were aligned using CLUSTAL_X 1.8 (Thompson et al., 1997).

Strains Cr9-30 ${ }^{\mathrm{T}}$ and Cr9-12 were routinely cultured in $\mathrm{R}_{2} \mathrm{~A}$ medium at $20{ }^{\circ} \mathrm{C}$ and maintained as a suspension in skimmed milk $(10 \%, \mathrm{w} / \mathrm{v})$ at $-80{ }^{\circ} \mathrm{C}$. Cell morphology was studied by phase-contrast microscopy $(\times 1000$ magnification) and by transmission electron microscopy (Libra 120 EFTEM; Zeiss). Motility was examined at 10 and $20{ }^{\circ} \mathrm{C}$ by microscopy $(\times 1000)$, by the API M system (bioMérieux) and additionally by the DSMZ (Braunschweig, Germany) on soft agar. Colonial morphology was observed on $\mathrm{R}_{2} \mathrm{~A}$ agar plates incubated at $20{ }^{\circ} \mathrm{C}$.
All tests described in this paragraph were done with strains $\mathrm{Cr} 9-30^{\mathrm{T}}$ and $\mathrm{Cr} 9-12$ and with the reference strains C. fungivorans LMG $21973^{\mathrm{T}}$, C. arenae LMG $23964^{\mathrm{T}}$ and C. pratensis LMG $23965^{\mathrm{T}}$. Gram-reaction was tested by standard Gram-staining. Catalase activity was determined by bubble production in $3 \%(\mathrm{v} / \mathrm{v}) \mathrm{H}_{2} \mathrm{O}_{2}$; oxidase activity was determined using $1 \%(\mathrm{w} / \mathrm{v}) \mathrm{N}, N, N^{\prime}, N^{\prime}$-tetramethylp-phenylenediamine. API strips (API 20E, API 20NE, API ZYM; bioMérieux) incubated at $20{ }^{\circ} \mathrm{C}$ were used according to the manufacturer's instructions to determine physiological and biochemical characteristics as well as enzyme activities of strains $\mathrm{Cr} 9-30^{\mathrm{T}}$ and $\mathrm{Cr} 9-12 . \beta$-Galactosidase, lipase esterase, amylase and protease activities were also tested by using $\mathrm{R}_{2} \mathrm{~A}$ agar plates supplemented with the appropriate substrates (Margesin et al., 2003). Chitinase activity was assayed on chitin-yeast agar as described by de Boer et al. (2004). The temperature range for growth was determined aerobically between 1 and $42{ }^{\circ} \mathrm{C}$ using $\mathrm{R}_{2} \mathrm{~A}$ medium. Growth at various $\mathrm{pH}$ values ( $\mathrm{pH} 5-9$ ) and salt tolerance $[0-10 \%(\mathrm{w} / \mathrm{v}) \mathrm{NaCl}]$ was determined on $\mathrm{R}_{2} \mathrm{~A}$ agar plates. Susceptibility to antibiotics was determined at 
$20{ }^{\circ} \mathrm{C}$ by using antibiotic discs (bioMérieux). Growth under anaerobic conditions was determined after 5 days of incubation at $20{ }^{\circ} \mathrm{C}$ in an anaerobic jar [containing Anaerocult A (Merck) to produce anaerobic conditions] on $\mathrm{R}_{2} \mathrm{~A}$ agar plates supplemented with $10 \mathrm{mM} \mathrm{KNO}_{3}$. Growth under microaerophilic conditions was assessed after 5 days at $20{ }^{\circ} \mathrm{C}$ on $\mathrm{R}_{2} \mathrm{~A}$ agar plates that were incubated in a microaerophilic atmosphere containing 8$10 \%(\mathrm{v} / \mathrm{v})$ carbon dioxide and 5-7\%(v/v) oxygen; this atmosphere was generated in sealed jars containing Anaerocult C (Merck). Features that serve to differentiate strains $\mathrm{Cr} 9-30^{\mathrm{T}}$ and $\mathrm{Cr} 9-12$ from the phylogenetically most closely related members of the genus Collimonas are given in Table 1. Morphological, physiological and biochemical characteristics of strains $\mathrm{Cr} 9-30^{\mathrm{T}}$ and $\mathrm{Cr} 9-12$ are given in the species description (see below) or are shown in Table 1.

Table 1. Differential phenotypic characteristics of strains $\mathrm{Cr} 9$ $30^{\top}$ and $\mathrm{Cr}$-12 and members of the genus Collimonas

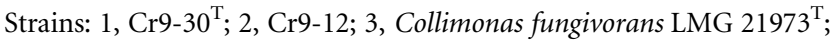
4, Collimonas arenae LMG $23964^{\mathrm{T}} ; 5$, Collimonas pratensis LMG $23965^{\mathrm{T}}$. All data are from this study. + , Positive; - , negative; $w$, weak. All strains are positive for acid phosphatase, alkaline phosphatase, esterase (C4), esterase lipase (C8), leucine arylamidase, naphthol-ASBI-phosphohydrolase activities and for assimilation of D-glucose and $\mathrm{L}$-arabinose. All strains are negative for $\beta$-glucuronidase, $\alpha$-glucosidase, $\beta$-glucosidase, $N$-acetyl- $\beta$-glucosaminidase, $\alpha$-mannosidase, $\alpha$-fucosidase, arginine dihydrolase, lysine dihydrolase and ornithine dihydrolase activities, for assimilation of maltose and phenylacetic acid, and for acid production from D-glucose, D-mannitol, sucrose, inositol, sorbitol, L-rhamnose, melibiose, amygdalin and L-arabinose.

\begin{tabular}{|c|c|c|c|c|c|}
\hline Characteristic & 1 & 2 & 3 & 4 & 5 \\
\hline Motility & - & - & + & + & + \\
\hline \multicolumn{6}{|l|}{ Growth at/in presence of: } \\
\hline $30{ }^{\circ} \mathrm{C}$ & - & - & + & + & + \\
\hline pH 5 & - & - & + & + & + \\
\hline $2 \%(\mathrm{w} / \mathrm{v}) \mathrm{NaCl}$ & - & $\mathrm{W}$ & $\mathrm{w}$ & + & + \\
\hline \multicolumn{6}{|l|}{ Enzyme activity: } \\
\hline Nitrate reduction & - & - & + & + & + \\
\hline Chitinase & - & - & + & + & + \\
\hline Lipase (C14) & - & $\mathrm{w}$ & + & + & + \\
\hline$\alpha$-Galactosidase & - & - & - & - & + \\
\hline$\beta$-Galactosidase & - & - & + & - & + \\
\hline Trypsin & - & - & $\mathrm{w}$ & + & + \\
\hline$\alpha$-Chymotrypsin & - & - & + & + & + \\
\hline Gelatinase & - & - & $\mathrm{w}$ & + & - \\
\hline Urease & - & - & - & + & - \\
\hline \multicolumn{6}{|c|}{ Assimilation of (API 20NE): } \\
\hline D-Mannose & - & - & + & $\mathrm{w}$ & + \\
\hline D-Mannitol & - & + & + & - & + \\
\hline $\mathrm{N}$-Acetylglucosamine & - & - & + & - & + \\
\hline Gluconate & + & + & - & $\mathrm{w}$ & w \\
\hline Capric acid & - & - & + & + & w \\
\hline Malic acid & - & + & + & + & + \\
\hline
\end{tabular}

For fatty acid methyl ester analysis, cell masses of strains Cr9-30 ${ }^{\mathrm{T}}, \mathrm{Cr} 9-12$ and C. fungivorans LMG $21973^{\mathrm{T}}$ (the type strain of the type species of the genus) were harvested from $\mathrm{R}_{2} \mathrm{~A}$ plates after incubation at $10{ }^{\circ} \mathrm{C}$ for 4 days. Fatty acid methyl esters were prepared and extracted according to the standard protocol of the MIDI (Microbial Identification) system (Sasser, 1990). The fatty acid profiles of strains Cr9$30^{\mathrm{T}}, \mathrm{Cr} 9-12$ and C. fungivorans LMG $21973^{\mathrm{T}}$ are shown in Table 2 . The predominant cellular fatty acids were summed feature $3\left(\mathrm{C}_{16: 1} \omega 7 c\right.$ and/or iso- $\left.\mathrm{C}_{15: 0} 2-\mathrm{OH}\right), \mathrm{C}_{16: 0}$ and $\mathrm{C}_{18: 1} \omega 7 c$.

The DNA G + C content of strain $\mathrm{Cr} 9-30^{\mathrm{T}}$, as determined by using standard HPLC analysis (Mesbah et al., 1989), was $51.0 \mathrm{~mol} \%$. Cellular fatty acids and DNA G $+\mathrm{C}$ content were both analysed by the Identification Service of the DSMZ.

Strains $\mathrm{Cr} 9-30^{\mathrm{T}}$ and $\mathrm{Cr} 9-12$ were isolated from the same site. No distinct differences were found between the two strains with regard to their morphological, physiological and biochemical characteristics, and their fatty acid profiles were almost identical. These data suggest that the two cryoconite strains belong to the same species. Similar cases have been described for representatives of the species Glaciibacter superstes (Katayama et al., 2009) and Undibacterium pigrum (Kämpfer et al., 2007). Within the family Oxalobacteraceae, strains $\mathrm{Cr} 9-30^{\mathrm{T}}$ and $\mathrm{Cr} 9-12$ formed a distinct subclade with three species of the genus Collimonas, which are the nearest phylogenetic neighbours of strain $\mathrm{Cr} 9-30^{\mathrm{T}}$. However, strain $\mathrm{Cr} 9-30^{\mathrm{T}}$ cannot be assigned to the genus Collimonas for the following reasons. (i) One unique continuous stretch of $18 \mathrm{bp}$ (V6 region), which is absent in all other recognized type strains of the family Oxalobacteraceae, but shared by members of the genus Collimonas and highly predictive of the genus Collimonas (de Boer et al., 2004; Höppener-Ogawa et al.,

Table 2. Cellular fatty acid compositions (\%) of strains Cr9-30 ${ }^{\top}$, Cr9-12 and C. fungivorans LMG $21973^{\top}$

Strains: $1, \mathrm{Cr} 9-30^{\mathrm{T}} ; 2$, Cr9-12; 3, C. fungivorans LMG $21973^{\mathrm{T}}$. Values are percentages of total fatty acids. ND, Not detected.

\begin{tabular}{|lrcc|}
\hline Fatty acid & $\mathbf{1}$ & $\mathbf{2}$ & $\mathbf{3}$ \\
\hline $\mathrm{C}_{10: 0}$ & 0.2 & 0.2 & $\mathrm{ND}$ \\
$\mathrm{C}_{10: 0}$ 3-OH & 1.6 & 1.2 & 1.1 \\
$\mathrm{C}_{12: 0}$ & 3.5 & 3.2 & 3.6 \\
$\mathrm{C}_{12: 0}$ 2-OH & 2.7 & 2.4 & 2.8 \\
$\mathrm{C}_{12: 0}$ 3-OH & 3.3 & 2.8 & 3.4 \\
Summed feature $3 *^{*}$ & 54.7 & 47.7 & 43.9 \\
$\mathrm{C}_{16: 0}$ & 17.5 & 22.5 & 23.4 \\
$\mathrm{C}_{16: 1}$ 2-OH & 1.6 & 0.8 & 2.7 \\
$\mathrm{C}_{17: 0}$ cyclo & 1.0 & 6.9 & 3.4 \\
$\mathrm{C}_{18: 1} \omega 7 c$ & 13.6 & 10.6 & 15.2 \\
$\mathrm{C}_{18: 0}$ & 0.5 & 0.7 & 0.5 \\
$11-$ methyl $\mathrm{C}_{18: 1} \omega 7 c$ & $\mathrm{ND}$ & 0.8 & $\mathrm{ND}$ \\
\hline
\end{tabular}

${ }^{\star}$ Summed feature 3 comprises $\mathrm{C}_{16: 1} \omega 7 c$ and/or iso- $\mathrm{C}_{15: 0}$ 2-OH. 
2008; Leveau et al., 2010), was absent in strain $\mathrm{Cr} 9-30^{\mathrm{T}}$. (ii) The DNA G $+\mathrm{C}$ content of strain $\mathrm{Cr} 9-30^{\mathrm{T}}(51.0 \mathrm{~mol} \%)$ was considerably lower than values reported for members of the genus Collimonas (57-62 mol\%). (iii) With regard to cellular fatty acids, strain $\mathrm{Cr} 9-30^{\mathrm{T}}$ contained higher amounts of summed feature $3\left(\mathrm{C}_{16: 1} \omega 7 \mathrm{c}\right.$ and/or iso$\left.\mathrm{C}_{15: 0} 2-\mathrm{OH}\right)$ and lower amounts of $\mathrm{C}_{16: 0}$ compared with the type strain of the type species of the genus Collimonas (see Table 2). (iv) Strain $\mathrm{Cr} 9-30^{\mathrm{T}}$ can be differentiated from all three recognized species of the genus Collimonas by a number of phenotypic properties (Table 1), e.g. strain $\mathrm{Cr} 9-30^{\mathrm{T}}$ is non-motile and negative for the following: growth at $30{ }^{\circ} \mathrm{C}$ and $\mathrm{pH} 5$; nitrate reduction; lipase (C14) and $\alpha$-chymotrypsin activities; and assimilation of capric acid, malic acid and trisodium citrate. In addition, strain $\mathrm{Cr} 9-30^{\mathrm{T}}$ is not able to hydrolyse colloidal chitin or milk proteins, which are typical characteristics of members of the genus Collimonas.

Thus, strains $\mathrm{Cr} 9-30^{\mathrm{T}}$ and $\mathrm{Cr} 9-12$ represent a novel species in a new genus, for which the name Glaciimonas immobilis gen. nov., sp. nov. is proposed.

\section{Description of Glaciimonas gen. nov.}

Glaciimonas (Gla.ci.i.mo'nas. L. fem. n. glacies ice; L. n. monas a unit, monad; N.L. fem. n. Glaciimonas a cell from the glacier).

Cells are Gram-negative-staining, rod-shaped and nonmotile. Able to grow under aerobic and microaerophilic conditions; unable to grow under anaerobic conditions. Oxidase- and catalase-positive. Negative for nitrate reduction. The predominant cellular fatty acids are summed feature $3\left(\mathrm{C}_{16: 1} \omega 7 c\right.$ and/or iso- $\left.\mathrm{C}_{15: 0} 2-\mathrm{OH}\right), \mathrm{C}_{16: 0}$ and $\mathrm{C}_{18: 1} \omega 7 \mathrm{c}$. The most closely related genus phylogenetically is Collimonas. The genus is affiliated to the family Oxalobacteraceae of the order Burkholderiales (class Betaproteobacteria). The type species is Glaciimonas immobilis.

\section{Description of Glaciimonas immobilis sp. nov.}

Glaciimonas immobilis (im.mo'bi.lis. L. fem. adj. immobilis motionless).

In addition to the characteristics listed above for the genus, the following properties are observed. Cells are 0.9$1.0 \times 1.1-1.5 \mu \mathrm{m}$ in size after 7 days at $20{ }^{\circ} \mathrm{C}$ on $\mathrm{R}_{2} \mathrm{~A}$ agar plates. Flagella or pili are absent. Colonies on $\mathrm{R}_{2} \mathrm{~A}$ agar are white, round, convex and smooth with entire margins; slime is produced. Good growth occurs in liquid $\mathrm{R}_{2} \mathrm{~A}$ medium and on $\mathrm{R}_{2} \mathrm{~A}$ agar plates at $1-20{ }^{\circ} \mathrm{C}$; growth at $25{ }^{\circ} \mathrm{C}$ is absent on agar plates and weak in liquid culture. Growth is weak on nutrient agar plates and almost absent on tryptic soy agar plates at $20{ }^{\circ} \mathrm{C}$. On $\mathrm{R}_{2} \mathrm{~A}$ agar plates, grows in the presence of $0-1 \%(\mathrm{w} / \mathrm{v}) \mathrm{NaCl}$ and at $\mathrm{pH} 6-8$. Negative for indole and $\mathrm{H}_{2} \mathrm{~S}$ production, hydrolysis of urease, aesculin, gelatin, milk proteins (skimmed milk) and starch. Negative for arginine dihydrolase, lysine dihydrolase and ornithine dihydrolase. In the API ZYM system, positive for acid phosphatase, alkaline phosphatase, leucine arylamidase, naphthol-AS-BIphosphohydrolase, esterase (C4) and esterase lipase (C8) activities. Valine arylamidase activity is weak. Negative for lipase (C14), trypsin, $\alpha$-chymotrypsin, $N$-acetyl$\beta$-glucosaminidase, $\alpha$-galactosidase, $\beta$-galactosidase, $\beta$ glucuronidase, $\alpha$-glucosidase, $\beta$-glucosidase, $\alpha$-mannosidase and $\alpha$-fucosidase activities. In the API 20NE system, positive for assimilation of D-glucose, L-arabinose and potassium gluconate. D-Mannose, D-mannitol, maltose, $\mathrm{N}$ acetylglucosamine, trisodium citrate, capric acid, adipic acid, malic acid and phenylacetic acid are not assimilated. Negative for acid production from D-glucose, D-mannitol, sucrose, inositol, D-sorbitol, L-rhamnose, D-melibiose, amygdalin and L-arabinose. Resistant to ampicillin (10 $\mu \mathrm{g})$, fusidinic acid $(10 \mu \mathrm{g})$ and erythromycin $(15 \mu \mathrm{g})$; sensitive to streptomycin $(10 \mu \mathrm{g})$, chloramphenicol $(30 \mu \mathrm{g})$, tetracycline $(30 \mu \mathrm{g})$, kanamycin $(30 \mu \mathrm{g})$, gentamicin $(10 \mu \mathrm{g})$, amikacin $(30 \mu \mathrm{g})$, rifampicin $(30 \mu \mathrm{g})$ and nalidixic acid $(30 \mu \mathrm{g})$.

The type strain is Cr9- $30^{\mathrm{T}}\left(=\mathrm{DSM} 23240^{\mathrm{T}}=\mathrm{LMG} 25547^{\mathrm{T}}\right)$, isolated from alpine glacier cryoconite collected from the Tiefenbachferner glacier in the Oetztaler Alps, Tyrol, Austria. The DNA G $+\mathrm{C}$ content of strain $\mathrm{Cr} 9-30^{\mathrm{T}}$ is $51.0 \mathrm{~mol} \%$. Strain Cr9-12 (=DSM 22814), isolated from the same source, is a second strain of the species.

\section{Acknowledgements}

We are grateful to Dr W. De Boer (Netherlands Institute for Ecology) for providing us with Collimonas pratensis LMG $23965^{\mathrm{T}}$, Collimonas arenae LMG $23964^{\mathrm{T}}$ and Collimonas fungivorans LMG $21973^{\mathrm{T}}$, and for useful information regarding the determination of chitinolytic activity. W. Salvenmoser (Institute of Zoology, University of Innsbruck) is acknowledged for performing transmission electron microscopy. We thank P. Thurnbichler for technical assistance. R. M. thanks the 'Aktion D. Swarovski \& Co. 2009' at the University of Innsbruck for financial support.

\section{References}

Cavicchioli, R. (2006). Cold-adapted archaea. Nat Rev Microbiol 4, 331-343.

de Boer, W., Leveau, J. H. J., Kowalchuk, G. A., Klein Gunnewiek, P. J. A., Abeln, E. C. A., Figge, M. J., Sjollema, K., Janse, J. D. \& van Veen, J. A. (2004). Collimonas fungivorans gen. nov., sp. nov., a chitinolytic soil bacterium with the ability to grow on living fungal hyphae. Int J Syst Evol Microbiol 54, 857-864.

Eder, W., Wanner, G., Ludwig, W., Busse, H.-J., Ziemke-Kägeler, F. \& Lang, E. (2011). Description of Undibacterium oligocarboniphilum sp. nov., isolated from purified water, and Undibacterium pigrum strain CCUG 49012 as the type strain of Undibacterium parvum sp. nov., and emended descriptions of the genus Undibacterium and the species Undibacterium pigrum. Int J Syst Evol Microbiol 61, 384-391.

Feller, G. \& Gerday, C. (2003). Psychrophilic enzymes: hot topics in cold adaptation. Nat Rev Microbiol 1, 200-208.

Felsenstein, J. (2009). PHYLIP (phylogeny inference package), version 3.69. Distributed by the author. Department of Genome Sciences, University of Washington, Seattle, USA. 
Garrity, G. M., Bell, J. A. \& Lilburn, T. (2005). Family II. Oxalobacteraceae fam. nov. In Bergey's Manual of Systematic Bacteriology, 2nd edn, vol. 2C, p. 623. Edited by D. J. Brenner, N. R. Krieg, J. T. Staley \& G. M. Garrity. New York: Springer.

Höppener-Ogawa, S., de Boer, W., Leveau, J. H. J., van Veen, J. A., de Brandt, E., Vanlaere, E., Sutton, H., Dare, D. J. \& Vandamme, P. (2008). Collimonas arenae sp. nov. and Collimonas pratensis sp. nov., isolated from (semi-)natural grassland soils. Int J Syst Evol Microbiol 58, 414-419.

Kämpfer, P., Rosselló-Mora, R., Hermansson, M., Persson, F., Huber, B., Falsen, E. \& Busse, H.-J. (2007). Undibacterium pigrum gen. nov., sp. nov., isolated from drinking water. Int J Syst Evol Microbiol 57, 1510-1515.

Katayama, T., Kato, T., Tanaka, M., Douglas, T. A., Brouchkov, A., Fukuda, M., Tomita, F. \& Asano, K. (2009). Glaciibacter superstes gen. nov., sp. nov., a novel member of the family Microbacteriaceae isolated from a permafrost ice wedge. Int J Syst Evol Microbiol 59, 482-486.

Kumar, S., Tamura, K. \& Nei, M. (2004). MEGA3: integrated software for molecular evolutionary genetics analysis and sequence alignment. Brief Bioinform 5, 150-163.

Leveau, J. H. J., Uroz, S. \& de Boer, W. (2010). The bacterial genus Collimonas: mycophagy, weathering and other adaptive solutions to life in oligotrophic soil environments. Environ Microbiol 12, 281-292.

Loveland-Curtze, J., Miteva, V. I. \& Brenchley, J. E. (2009). Herminiimonas glaciei sp. nov., a novel ultramicrobacterium from $3042 \mathrm{~m}$ deep Greenland glacial ice. Int J Syst Evol Microbiol 59, 12721277.

Margesin, R. (2009). Effect of temperature on growth parameters of psychrophilic bacteria and yeasts. Extremophiles 13, 257-262.
Margesin, R., Gander, S., Zacke, G., Gounot, A. M. \& Schinner, F. (2003). Hydrocarbon degradation and enzyme activities of coldadapted bacteria and yeasts. Extremophiles 7, 451-458.

Margesin, R., Schinner, F., Marx, J. C. \& Gerday, C. (editors) (2008). Psychrophiles: from Biodiversity to Biotechnology. Berlin/Heidelberg: Springer.

Mesbah, M., Premachandran, U. \& Whitman, W. B. (1989). Precise measurement of the $\mathrm{G}+\mathrm{C}$ content of deoxyribonucleic acid by high-performance liquid chromatography. Int J Syst Bacteriol 39, 159-167.

Morita, R. Y. (1975). Psychrophilic bacteria. Bacteriol Rev 39, 144-167.

Reasoner, D. J. \& Geldreich, E. E. (1985). A new medium for the enumeration and subculture of bacteria from potable water. Appl Environ Microbiol 49, 1-7.

Sambrook, J., Fritsch, E. F. \& Maniatis, T. (1989). Molecular Cloning: a Laboratory Manual, 2nd edn. Cold Spring Harbor, NY: Cold Spring Harbor Laboratory.

Sasser, M. (1990). Identification of bacteria by gas chromatography of cellular fatty acids, MIDI Technical Note 101. Newark, DE: MIDI.

Thompson, J. D., Gibson, T. J., Plewniak, F., Jeanmougin, F. \& Higgins, D. G. (1997). The CLUSTAL_X windows interface: flexible strategies for multiple sequence alignment aided by quality analysis tools. Nucleic Acids Res 25, 4876-4882.

Zhang, D.-C., Schinner, F. \& Margesin, R. (2010). Pedobacter bauzanensis sp. nov., isolated from soil. Int J Syst Evol Microbiol 60, 2592-2595.

Zul, D., Wanner, G. \& Overmann, J. (2008). Massilia brevitalea sp. nov., a novel betaproteobacterium isolated from lysimeter soil. Int J Syst Evol Microbiol 58, 1245-1251. 